\title{
Comparison of Intravenous, Intra-articular, and Combined Tranexamic Acid Use in Primary Total Knee Arthroplasty without a Tourniquet and a Drain
}

\section{Turnike ve Dren Olmadan Primer Total Diz Artroplastisinde İntravenöz, İntra-artiküler ve Kombine Traneksamik Asit Kullanımının Karşılaştırılması}

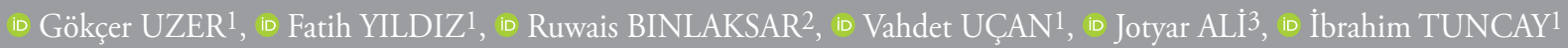

${ }^{1}$ Bezmialem Vakıf University Faculty of Medicine, Department of Orthopedics and Traumatology, İstanbul, Turkey

${ }_{2}^{2}$ Binzella Hospital, Clinic of Orthopedics and Traumatology, Yemen

${ }^{3}$ Kiziltepe State Hospital, Clinic of Orthopedics and Traumatology, Mardin, Turkey

\section{ABSTRACT}

Objective: We assessed the effect of tranexamic acid (TXA) route of administration on the estimated blood loss (EBL) in patients undergoing primary total knee arthroplasty (TKA) without tourniquet and drain use.

Methods: One hundred fifty three patients who underwent primary TKA with use of TXA, between December 2012 and February 2016 were evaluated retrospectively. The patients were divided into three groups according to the route of TXA use: group I, $2 \mathrm{~g}$ of intravenous (IV; $\mathrm{n}=50$ ); group II, $2 \mathrm{~g}$ of intraarticular (IA, $\mathrm{n}=50$ ); and group III, $1 \mathrm{~g}$ of IV and $1 \mathrm{~g}$ IA combined use $(\mathrm{n}=53)$. We recorded the body mass indexes, the platelet counts, haemoglobin, haematocrit levels, prothrombin time, partial thromboplastin time, and international normalised ratio, preoperatively and at $1^{\text {st }}$ and $7^{\text {th }}$ days, postoperatively. EBL was calculated using Meunier's formula.

Results: On the first day, the mean EBLs for groups I to III were $286.3 \pm 128.8 \mathrm{~mL}, \quad 342.7 \pm 176.0 \mathrm{~mL}$, and $379.7 \pm 228.9$ $\mathrm{mL}$, respectively $(\mathrm{p}=0.029$ for group I vs. group III). On 7 th day postoperatively, they were calculated as $823 \pm 619.3 \mathrm{~mL}$, $1175.1 \pm 970.5 \mathrm{~mL}$, and $1092.2 \pm 766.7 \mathrm{~mL}$ ( $\mathrm{p}=0.073$ ) During the first 90 days postoperatively, we did not see any symptomatic thromboembolic complications, delayed haemorrhage, or surgical site or periprosthetic infections.

\section{ÖZ}

Amaç: Turnike ve dren kullanmadan primer total diz artroplastisi (TDA) geçiren hastalarda traneksamik asit (TXA) uygulama yolunun tahmini kan kaybı (EBL) üzerindeki etkisini değerlendirdik.

Yöntemler: Aralık 2012-Şubat 2016 tarihleri arasında TXA kullanılarak primer TDA uygulanan 103 hasta retrospektif olarak incelendi. Hastalar TXA kullanım yoluna göre üç gruba ayrıldı: grup I, $2 \mathrm{~g}$ intravenöz (IV; $\mathrm{n}=25$ ); grup II, $2 \mathrm{~g}$ intraartiküler (IA, $\mathrm{n}=25$ ); ve grup III, $1 \mathrm{~g}$ IV ve $1 \mathrm{~g}$ IA kombine kullanım ( $\mathrm{n}=53$ ). Vücut kitle endeksleri, platalet sayımı, hemoglobin, hematokrit seviyeleri, protrombin zamanı (PT), parsiyel tromboplastin zamanı (PTT) ve internationel normalized ratio (INR) preop, postop 1. ve 7. günde değerlendirdik. EBL, meunier formülü kullanılarak hesaplandı.

Bulgular: İlk gün I ila III. grupların ortalama EBL'leri sırasıyla $286,3 \pm 130,15 \mathrm{~mL}, 342,7 \pm 177,87 \mathrm{~mL}$ ve $379,7 \pm 228,85 \mathrm{~mL}$ idi ve istatistiksel olarak farklı değildi $(\mathrm{p}=0,152)$. Ameliyat sonrası 7 . günde $823 \pm 625,75 \mathrm{~mL}, 1175,1 \pm 980,6 \mathrm{~mL}$ ve $1092,2-766,7 \mathrm{~mL}$ $(\mathrm{p}=0,250)$ ameliyattan sonraki ilk 90 gün boyunca herhangi bir semptomatik tromboembolik komplikasyon, gecikmiş kanama veya cerrahi bölge veya periprostetik enfeksiyon görülmedi.
Address for Correspondence: Vahdet UÇAN, Bezmialem Vakıf University Faculty of Medicine, Department of Orthopedics and Traumatalogy, İstanbul, Turkey

Phone: +90 5546546750 E-mail: vahdetucan@hotmail.com ORCID ID: orcid.org/0000-0002-6552-9197 articular, and Combined Tranexamic Acid Use in Primary Total Knee Arthroplasty without a Tourniquet and a Drain. Bezmialem Science 2020;8(2):120-4. 
Conclusion: IV, IA or combined uses of TXA are effective and safe for reducing blood loss and transfusion requirements in primary TKA without a tourniquet and drain.

Keywords: Tranexamic acid, total knee arthroplasty, blood loss
Sonuç: IV, IA veya TXA'nın kombine kullanımları, turnike ve drenaj olmadan primer TDA'da kan kaybını ve transfüzyon gereksinimlerini azaltmak için etkili ve güvenlidir.

Anahtar Sözcïkler: Traneksamik asit, total diz artroplastisi, kan kaybi

\section{Introduction}

Total knee arthroplasty (TKA) is the surgical option used most frequently in the treatment of symptomatic knee osteoarthritis and it usually results in patient satisfaction. However, it is prone to several complications related to the $800-1500 \mathrm{~mL}$ blood loss involved and the requirement for intraoperative and early postoperative allogeneic blood transfusions in 10$30 \%$ of patients (1-8). Decreasing the rate of blood loss and the need for allogeneic blood transfusion is very important in TKA for improving functional recovery and decreasing transfusion-related risks and costs (9). Tranexamic acid (TXA) is a potent antifibrinolytic agent that decreases bleeding in TKA by preventing fibrinolytic activity. It acts by binding to the lysine-binding area of plasminogen, consequently blocking the attachment of plasminogen to fibrin. The half-life of TXA, which has been used safely since 1964 , is $1.9-2.7 \mathrm{~h}$ and a large amount of TXA is excreted in urine without being metabolised when used intravenously $(10,11)$. Recent meta-analyses have revealed that antifibrinolytics are safe and cost-effective, and they decrease the need for blood transfusion and shorten the hospital stay $(1,12)$.

The literature contains no reports on adverse thromboembolic events related to the intravenous (IV) administration of 1-3 g TXA in TKA, but there are potential advantages in terms of tolerability and decreased costs (13). Topical TXA use decreases the plasma TXA concentration ten-fold compared with an IV dose and has $70 \%$ less systemic absorption, which decreases the likelihood of adverse effects (14). In addition, to maintain microvascular haemostasis, it is important to reach maximum concentrations at the surgical site (15). The effectiveness of intraarticular (IA) TXA compared to IV administration has not been proven. In some studies, IA TXA reduced postoperative swelling around the knee compared with placebo $(16,17)$. However, there is still no clear evidence whether IA administration has similar effects with IV application.

The literature on the combined IV and IA use of TXA is limited; almost all of the available studies involved tourniquet use, which stimulated fibrinolysis and consequently bleeding (1820). Therefore, this comparative retrospective study assessed the effect of TXA route of administration (IV, IA, or combined) on the estimated blood loss in patients undergoing primary TKA without tourniquet and drain use.

\section{Methods}

This retrospective study included 103 patients with tricompartmental osteoarthritis who underwent primary TKA between December 2012 and February 2016. Patients using anticoagulant or anti-aggregant medications (such as enoxaparin, fondaparinux, clopidogrel, Factor Xa, or thrombin inhibitors) and oral contraceptives, having thrombophilia, oncological disease, hepatic or renal dysfunction, a history of myocardial infarction, deep venous thrombosis (DVT), and alcohol abuse were excluded. The patients were divided into three groups according to the route of TXA use: Group I, $2 \mathrm{~g}$ IV [n=50; 46 females, 4 males; mean age, 65.9 (range $=46-77$ ) years]; group II, $2 \mathrm{~g}$ IA [ $\mathrm{n}=50 ; 40$ females, 10 males; mean age, 70 (range $=59-80$ ) years]; and group III, g IV and $1 \mathrm{~g}$ IA together [ $\mathrm{n}=53 ; 46$ females, 7 males; mean age, 66.3 (range= 54-87) years].

All of the surgeries were performed by three arthroplasty surgeons under spinal anaesthesia and without use of a tourniquet and Hemovac drains. We administered $2 \mathrm{~g}$ of IV cefazolin for infection prophylaxis, $30 \mathrm{~min}$ before the incision. All patients underwent cemented, cruciate-retaining, tricompartmental TKA using a medial parapatellar approach. Group I was given $2 \mathrm{~g}$ TXA in $100 \mathrm{~mL}$ of saline, intravenously. Group II was given $2 \mathrm{~g}$ of TXA in $30 \mathrm{~mL}$ of saline injected intra-articularly after closing the joint capsule. Group III was given $1 \mathrm{~g}$ of TXA in $100 \mathrm{~mL}$ saline intravenously and $1 \mathrm{~g}$ in $15 \mathrm{~mL}$ of saline intraarticularly. During the postoperative period, we administered 1 $\mathrm{g}$ IV cefazolin for infection prophylaxis for $24 \mathrm{~h}$ and $0.4 \mathrm{~mL}$ of enoxaparin for DVT prophylaxis for 2 days. On the third day, the patients were discharged and advised to take $100 \mathrm{mg}$ oral aspirin daily and to use anti-embolic socks for the next 6 weeks.

We recorded the body mass index (BMI) preoperatively, and the platelet count, haemoglobin level $(\mathrm{Hb})$, haematocrit $(\mathrm{Hct})$ and international normalised ratio (INR), preoperatively and on $1^{\text {st }}$ and $7^{\text {th }}$ days, postoperatively. The blood loss was estimated using the Meunier's formula: (21)

Estimated blood loss volume $(\mathrm{EBV})=\mathrm{BV} \times\left(\mathrm{Hb}_{\mathrm{i}}-\mathrm{Hb}_{\mathrm{f}}\right) / \mathrm{Hb}_{\mathrm{i}}$, where $\mathrm{BV}$ is the estimated blood volume [=weight $\times$ average blood volume $(75 \mathrm{~mL} / \mathrm{kg}$ for males, $65 \mathrm{~mL} / \mathrm{kg}$ for females], $\mathrm{Hb}$ is the initial preoperative $\mathrm{Hb}$, and $\mathrm{Hb}_{\mathrm{f}}$ is the $\mathrm{Hb}$ on a given day postoperatively.

The estimated blood losses of the three groups were compared. Patients were investigated for thromboembolic complications, delayed haemorrhage, and periprosthetic infection for 3 months postoperatively.

\section{Statistical Analyses}

The data were analysed using one-way analysis of variance (ANOVA) with post hoc tests, using the program SPSS. A p value $<0.05$ was defined as statistically significant with $95 \%$ confidence interval. 


\section{Results}

The mean BMI and its range in groups I to III were 34.4 $(23-47), 33.2(26-43)$, and $33.7(23-50) \mathrm{kg} / \mathrm{m}^{2}$, respectively $(p=0.537)$. The demographic information for the three groups and preoperative $\mathrm{Hb}$, Hct, and EBV values are shown in Table 1. On the first day, the mean EBV and its standard deviation in groups I to III were 286.3 (128.8), 342.7 (176.0), and 379.7 (228.9) $\mathrm{mL}$, respectively, and did not differ statistically among the groups. The mean EBV was significantly lower in the group I than the group III $(\mathrm{p}=0.029)$. There was no significant difference between group I and II $(\mathrm{p}=0.277)$ and between group II and III $(\mathrm{p}=0.564)$. On the $7^{\text {th }}$ postoperative day, the EBV values were 823 (619.3), 1175.1 (970.5), and 1092.2 (766.7) $\mathrm{mL}$, respectively $(\mathrm{p}=0.073)$ (Table 2$)$.

During the first 90 days postoperatively, we did not see any symptomatic thromboembolic complications, delayed haemorrhage, or surgical site or periprosthetic infections.

\section{Discussion}

There is still no consensus on the dosage and route of administration of TXA in orthopaedic surgery. Adequate blockage of fibrinolysis in the tissues requires an approximately $80 \%$ decrease in plasminogen activity. For this reason, the plasma TXA concentration should be $10 \mathrm{ng} / \mathrm{mL}$ and this plasma concentration can be obtained with a $10 \mathrm{mg} / \mathrm{kg}$ dose of IV TXA in $3 \mathrm{~h}$ (22). In the literature, TXA decreased the need for blood transfusion by up to $38 \%$ in orthopaedic, cardiovascular, cranial, and general surgeries (23). The estimated blood loss in groups I and III showed that both dosages were sufficient for reaching the effective plasma concentration.

Topical TXA has less systemic absorption and higher local concentrations compared with IV administration, which means it has fewer systemic side effects. It also decreases the need for transfusion 13-fold compared with placebo $(10,15,24)$. Wang et al. (15) reported that IV TXA was not superior to IA administration in reducing blood loss or the need for transfusion. Maniar et al. (22) showed that a single $3 \mathrm{~g}$ IA TXA dose is as effective as single $10 \mathrm{mg} / \mathrm{kg}$ IV TXA dose. A review by Pantelli et al. (25) compared topical TXA application of less than $2 \mathrm{~g}$ and more than $2 \mathrm{~g}$ with placebo and found that both dosages decreased the rate of transfusion need, although the decrease was not significant in the group who received less

\section{Table 1. Demographic data and preoperative blood counts}

\begin{tabular}{|c|c|c|c|c|}
\hline & IV group & IA group & Combined group & $P$ value \\
\hline No. of patients (M/F) & $50(4 / 46)$ & $50(10 / 40)$ & $53(7 / 46)$ & \\
\hline Age (SD) & $65.9(8.3)$ & $70.1(6.7)$ & $66.3(8)$ & 0.101 \\
\hline BMI $\left(\mathrm{kg} / \mathrm{m}^{2}\right)(\mathrm{SD})$ & $34.4(6.5)$ & $33.2(4.5)$ & $33.7(5.3)$ & 0.537 \\
\hline Preop. Hb (g/dL) & $12.6(1.6)$ & $12.7(1.4)$ & $12.8(1.4)$ & 0.741 \\
\hline Preop. Hct (\%) & $37.6(4.3)$ & $38.8(3.5)$ & $39.4(3.7)$ & 0.061 \\
\hline Preop platelet count X1000 & $267.7(73.6)$ & $254.7(62.5)$ & $271.4(98)$ & 0.541 \\
\hline Preop INR & $1.05(0.10)$ & $1.14(0.21)$ & $1.05(0.21)$ & 0.131 \\
\hline Estimated blood volume (mL) (SD) & 5666.7 (1019) & $5727.8(779.7)$ & $5648.1(1046.4)$ & 0.908 \\
\hline
\end{tabular}

SD: Standard deviation, HcT: Haematocrit, Hb: Haemoglobin , INR: International normalised ratio

Table 2. Summary of the data on the first and seventh postoperative days

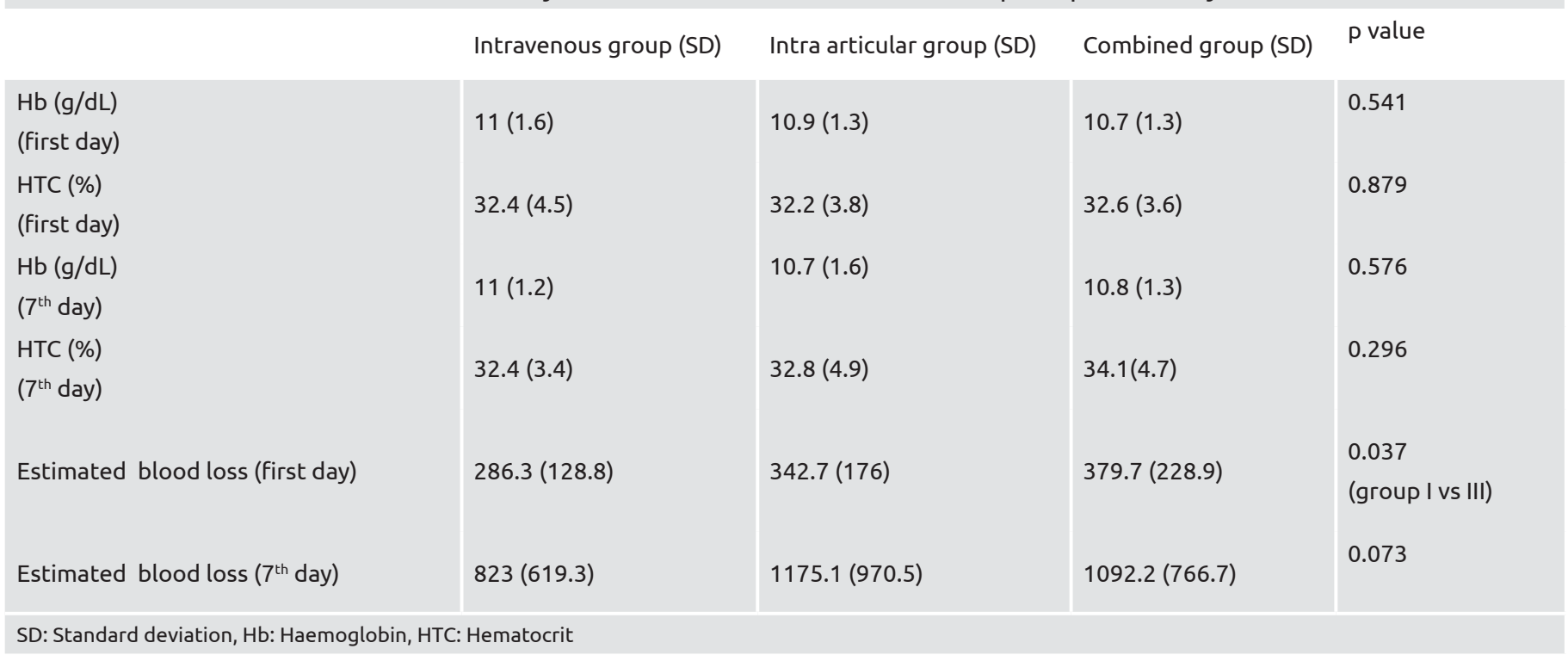


than $2 \mathrm{~g}$ topical TXA. In their topical TXA group, the decrease in the postoperative $\mathrm{Hb}$ level was around $1 \mathrm{~g} / \mathrm{dL}$. In our study, the means of decrease in the $\mathrm{Hb}$ level on the first postoperative day in groups I to III were $1.6 \pm 0.6,1.9 \pm 0.9$, and $2.1 \pm 1.0 \mathrm{~g} / \mathrm{dL}$, respectively $(\mathrm{p}=0.009)$. On day 7 , the differences between the pre- and postoperative $\mathrm{Hb}$ levels in groups I to III were $1.6 \pm 1.1$, $2.0 \pm 1.4$, and $2.0 \pm 1.2 \mathrm{~g} / \mathrm{dL}$, respectively $(\mathrm{p}=0.133)$. Although there was a statistically significant difference in terms of the mean $\mathrm{Hb}$ loss in the first postoperative day between groups I and III, which might not have a clinical importance, no statistical difference was seen in the $7^{\text {th }}$ postoperative day. Postoperatively, no symptomatic anaemia or need for blood transfusion was seen in any patient.

Although TXA is expected to increase the rates of DVT and pulmonary embolism due to its antifibrinolytic activity, Astedt et al. (26) reported that TXA did not exert its antifibrinolytic activity on the walls of veins and it protected against thrombosis. Moreover, several studies have proven that TXA decreases blood loss without increasing the incidence of DVT or thromboembolic events $(10,27,28)$. We did not see a symptomatic DVT or pulmonary embolism in any patient and in parallel with the literature, we think that this is a consequence of using TXA and not using a tourniquet in our study.

This study had some limitations. First, it was a retrospective study with a limited number of patients. It would have been better if we had groups with tourniquet or drain use or combined use of them. Lastly, we could not compare the results of different dosages of TXA.

\section{Conclusion}

Intravenous, intra-articular, or combined use of TXA is effective and safe for reducing blood loss and transfusion requirements in primary TKA without using tourniquet and drains.

\section{Ethics}

Ethics Committee Approval: Retrospective study.

Informed Consent: Retrospective study.

Peer-review: Externally peer reviewed.

\section{Authorship Contributions}

Surgical and Medical Practices: G.U., F.Y., İ.T., V.U., J.A., Concept: F.Y., İ.T., Design: İ.T., F.Y., Data Collection or Processing: V.U., J.A., G.U., Analysis or Interpretation: İ.T., G.U., F.Y., Literature Search: R.B., G.U., Writing: G.U., F.Y.

Conflict of Interest: No conflict of interest was declared by the authors.

Financial Disclosure: The authors declared that this study received no financial support.

\section{References}

1. Jain NP, Nisthane PP, Shah NA. Combined Administration of Systemic and Topical Tranexamic Acid for Total Knee Arthroplasty:
Can It Be a Better Regimen and Yet Safe? A Randomized Controlled Trial. J Arthroplasty 2019;31:542-7.

2. Callaghan JJ, O’Rourke MR, Liu SS. Blood management: issues and options. J Arthroplasty 2005;20(4 Suppl 2):51.

3. Wong J, Abrishami A, El Beheiry H, Mahomed NN, Roderick Davey J, Gandhi R, Syed KA, Muhammad Ovais Hasan S, De Silva Y, Chung F. Topical application of tranexamic acid reduces postoperative blood loss in total knee arthroplasty: a randomized, controlled trial. J Bone Joint Surg Am 2010;92:2503.

4. Charoencholvanich K, Siriwattanasakul P. Tranexamic acid reduces blood loss and blood transfusion after TKA: a prospective randomized controlled trial. Clin Orthop Relat Res 2011;469:2874.

5. Hiippala ST, Strid LJ, Wennerstrand MI, Arvela JV, Niemela HM, Mantyla SK, Kuisma RP, Ylinen JE. Tranexamic acid radically decreases blood loss and transfusions associated with total knee arthroplasty. Anesth Analg 1997;84:839.

6. Goodnough LT, Verbrugge D, Marcus RE. The relationship between hematocrit, blood lost, and blood transfused in total knee replacement. Implications for postoperative blood salvage and reinfusion. Am J Knee Surg 1995;8:83

7. Bong MR, Patel V, Chang E, Issack PS, Hebert R, Di Cesare PE. Risks associated with blood transfusion after total knee arthroplasty. J Arthroplasty 2004;19:281.

8. Good L, Peterson E, Lisander B. Tranexamic acid decreases external blood loss but not hidden blood loss in total knee replacement. Br J Anaesth 2003;90:596.

9. Husted H. Fast-track hip and knee arthroplasty: clinical and organizational aspects. . Acta Orthop 2012;Suppl 83:1.

10. Alshryda S, Mason J, Vaghela M, Sarda P, Nargol A, Maheswaran S, Tulloch C, Anand S, Logishetty R, Stothart B, Hungin AP. Topical (intra-articular) tranexamic acid reduces blood loss and transfusion rates following total knee replacement: a randomized controlled trial (TRANX-K). J Bone Joint Surg Am 2013;95:1961.

11. Kim C, Park SS, Davey JR. Tranexamic acid for the prevention and management of orthopedic surgical hemorrhage: current evidence. J Blood Med 2015;6:239.

12. Chen TT, Jiandong L, Wang G, Jiang SL, Li LB, Gao CQ. Combined treatment of ulinastatin and tranexamic acid provides beneficial effects by inhibiting inflammatory and fibrinolytic response in patients undergoing heart valve replacement surgery. Heart Surg Forum 2013;16:E38.

13. Smit KM, Naudie DD, Ralley FE, Berta DM, Howard JL. One dose of tranexamic acid is safe and effective in revision knee arthroplasty. J Arthroplasty 2013;28(8Suppl):112.

14. Ng W, Jerath A, Wasowicz M. Tranexamic acid: a clinical review. Anaesthesiol Intensive Ther 2015;47:339.

15. Wang H, Shen B, Zeng Y. Comparison of topical versus intravenous tranexamic acid in primary total knee arthroplasty: a meta-analysis of randomized controlled and prospective cohort trials. Knee 2014;21:987.

16. Poeran J, Rasul R, Suzuki S, Danninger T, Mazumdar M, Opperer M, Boettner F, Memtsoudis SG. Tranexamic acid use and postoperative outcomes in patients undergoing total hip or knee arthroplasty in the 
United States: retrospective analysis of effectiveness and safety. BMJ 2014;349:4829.

17. Ishida K, Tsumura N, Kitagawa A, Hamamura S, Fukuda K, Dogaki Y, Kubo S, Matsumoto T, Matsushita T, Chin T, Iguchi T, Kurosaka M, Kuroda R. Intra-articular injection of tranexamic acid reduces not only blood loss but also knee joint swelling after total knee arthroplasty. Int Orthop 2011;35:1639.

18. Roy SP, Tanki UF, Dutta A, Jain SK, Nagi ON. Efficacy of intraarticular tranexamic acid in blood loss reduction following primary unilateral total knee arthroplasty. Knee Surg Sports Traumatol Arthrosc 2012;20:2494.

19. Karaaslan F, Karaoglu S, Mermerkaya MU, Baktir A. Reducing blood loss in simultaneous bilateral total knee arthroplasty: combined intravenous-intra-articular tranexamic acid administration. A prospective randomized controlled trial. Knee 2015;22:131.

20. Fahmy NR, Patel DG. Hemostatic changes and postoperative deepvein thrombosis associated with use of a pneumatic tourniquet. J Bone Joint Surg Am 1981;63:461.

21. Meunier A, Petersson A, Good L, Berlin G. Validation of a haemoglobin dilution method for estimation of blood loss. Vox Sang 2008;95:120.

22. Maniar RN, Kumar G, Singhi T, Nayak RM, Maniar PR. Most effective regimen of tranexamic acid in knee arthroplasty: a prospective randomized controlled study in 240 patients. Clin Orthop Relat Res 2012; $470: 2605$.

23. Ker K, Edwards P, Perel P, Shakur H, Roberts I. Effect of tranexamic acid on surgical bleeding: systematic review and cumulative metaanalysis. BMJ 2012;344:e3054.

24. Damji KF, Noel LP, Peterson RG, Ma PE, Clarke WN, Gilberg $S$, Crouch ER, Jr., Williams PB. Topical versus intravenous administration of tranexamic acid: a comparison of intraocular and serum concentrations in the rabbit. Can J Ophthalmol 1998;33:308.

25. Panteli M, Papakostidis C, Dahabreh Z, Giannoudis PV. Topical tranexamic acid in total knee replacement: a systematic review and meta-analysis. Knee 2013;20:300.

26. Astedt B, Liedholm P, Wingerup L. The effect of tranexamic acid on the fibrinolytic activity of vein walls. Ann Chir Gynaecol 1978;67:203.

27. Zhang F, Wang K, Li FN, Huang X, Li Q, Chen Z, Tang YB, Shen HX, Song QX. Effectiveness of tranexamic acid in reducing blood loss in spinal surgery: a meta-analysis. BMC Musculoskelet Disord 2014;15:448.

28. Tanaka N, Sakahashi H, Sato E, Hirose K, Ishima T, Ishii S. Timing of the administration of tranexamic acid for maximum reduction in blood loss in arthroplasty of the knee. J Bone Joint Surg Br 2001;83:702. 